Jurnal Penelitian dan Evaluasi Pendidikan

\title{
KONTRIBUSI STATUS SOSIAL EKONOMI KELUARGA DAN SIKAP KEBANGSAAN TERHADAP PRESTASI BELAJAR SEJARAH
}

\author{
Soepardjo \\ Universitas Nahdlatul Ulama Surakarta \\ J1. DR. Wahidin 05/VI, Penumping Laweyan, Surakarta 57141 \\ trisno_061@yahoo.com
}

\begin{abstract}
Abstrak
Penelitian ini bertujuan untuk mengetahui kontribusi 1) status sosial ekonomi keluarga terhadap prestasi belajar sejarah; 2) sikap kebangsaan siswa terhadap prestasi belajar sejarah; dan 3) status sosial ekonomi keluarga dan sikap kebangsaan secara bersamasama terhadap prestasi belajar sejarah. Metode penelitian yang digunakan adalah metode survei dengan desain korelasional. Populasi penelitian 980 siswa. Sampel penelitian 245 siswa yang diambil dengan teknik random sampling. Pengumpulan data menggunakan tes dan kuesioner. Teknik analisis data menggunakan teknik korelasi dan regresi. Hasil penelitian menunjukkan bahwa 1) kontribusi positif dan signifikan status sosial ekonomi keluarga terhadap prestasi belajar sejarah; 2) kontribusi positif dan signifikan sikap kebangsaan terhadap prestasi belajar sejarah; 3) kontribusi positif dan signifikan status sosial ekonomi keluarga dan sikap kebangsaan terhadap prestasi belajar sejarah pada siswa SMU Muhammadiyah Kota Surakarta.
\end{abstract}

Kata kunci: status sosial ekonomi, sikap kebangsaan, prestasi belajar sejarah 


\title{
CONTRIBUTION OF FAMILY'S SOCIO-ECONOMIC STATUS AND NATIONALISM ATTITUDE TOWARD HISTORY LEARNING ACHIEVEMENT
}

\author{
Soepardjo \\ Universitas Nahdlatul Ulama Surakarta \\ Jl. DR. Wahidin 05/VI, Penumping Laweyan, Surakarta 57141 \\ trisno_061@yahoo.com
}

\begin{abstract}
The study aims to determine: 1) family socioeconomic status on history learning achievement; 2) nationalism attitude toward students' history learning achievement; and 3) family socioeconomic status and nationalism attitude together towards achievement history. The research method used was a survey method with a correlational design. The study population was 980 students. 245 students sample were taken with random sampling technique. Data were collectied by using tests and questionnaires. The technique of data analysis used correlation and regression techniques. The results show that contribution of family socioeconomic status on history learning achievement was $9,02 \%$. Contributions of nationalism attitudes toward achievement in learning history was $5.59 \%$ and the contribution of family socioeconomic status and attitudes nationalities together towards achievement history was $2.13 \%$. From the result it can be concluded that there is a significant and positive contribution of 1) socio-economic status of the family; 2) nationalism attitudes; and3) socio-economic status of the family and national attitudes toward students learning history achievement at SMU Muhammadiyah Surakarta.
\end{abstract}

Keywords: socioeconomic status, nationalitism attitude, history learning achievement 


\section{Pendahuluan}

Penanaman dan pelestarian sikap kebangsaan adalah melalui proses pendidikan, sebab di dalamnya terkandung unsur pemahaman dalam rangka penguasaan Ilmu Pengetahuan dan Teknologi (IPTEK). Demi mencerdaskan kehidupan bangsa, pemerintah Indonesia menyelenggarakan pendidikan bagi warga negaranya berdasarkan Undang-Undang Dasar 1945, bab 8 pasal 31, ayat 1 dan 2. Adapun pasal dan ayat dimaksud, adalah “(1) Tiap-tiap warga negara berhak mendapat pengajaran. (2) Pemerintah mengusahakan dan menyelenggarakan satu sistem pengajaran nasional, yang diatur dengan undang-undang”, sedangkan sistem penyelenggaraan pengajaran tersebut diatur dalam Undang-Undang No. 20 tahun 2003 tentang Sistem Pendidikan Nasional.

Semua individu mempunyai kebutuhan hidup yang harus dipenuhi baik sebagai individu, sebagai keluarga, maupun sebagai masyarakat dan bangsa. Menurut A.H. Maslow, kebutuhan yang harus dipenuhi agar manusia dapat berkembang dengan baik adalah 1) kebutuhan biologis; 2) kebutuhan akan rasa aman; 3) kebutuhan akan cinta kasih dan rasa memiliki; 4) kebutuhan akan penghargaan; 5) kebutuhan untuk tahu; 6) kebutuhan akan keindahan; 7) kebutuhan akan kebebasan bertindak (aktualisasi diri) (Djaali, 2008:102). Agar dapat terpenuhi segala kebutuhan hidupnya, pendapatan keluarga harus didistribusikan secara baik, sebab pendapatan keluarga mempunyai peranan yang sangat menentukan terhadap terpenuhinya kebutuhan hidup keluarga.

Di samping ada anak sekolah yang droup out, banyak pula siswa Sekolah Lanjutan Tingkat Atas menunjukkan perilaku kurang mencintai bangsa dan negara. Hal itu terlihat adanya peristiwa tawuran, pembunuhan, perkosaan dan perkelahian antarsiswa, terutama di Jakarta dan kota-kota besar lainnya. Bahkan perkelahian antarsuku bangsa misalnya suku Dayak dan suku Madura, antarpemeluk agama yang satu dengan pemeluk agama yang lain. Peristiwa tersebut tampak akibat dari perilaku emosional yang tidak terpenuhi kebutuhan hidupnya secara layak terutama ekonomi, sehingga mereka lapar dan mudah marah. Keadaan tersebut sesuai dengan pernyataan Malian dan Marzuki (2003: 7) bahwa "nilai-nilai kejujuran, ke- 
sopanan, sikap tenggang rasa, saling tolong menolong dan ketundukan pada hukum seakan semakin menipis".

Pemerintah sudah melakukan kebijakan-kebijakan dan mengalokasikan anggaran belanja negara ke berbagai bidang pembangunan, di antaranya bidang pendidikan dengan tujuan agar semua anak Indonesia harus sekolah, sekurang-kurangnya mereka menikmati pendidikan dasar 9 tahun, sebagai program wajib belajar yang dicanangkan oleh pemerintah Indonesia tanggal 2 Mei 1984.

Sehubungan dengan uraian tersebut, dapat diasumsikan bahwa tinggi atau rendahnya ekonomi keluarga dan besar kecilnya sikap kebangsaan yang dimiliki, oleh orang tua, dan anak akan berpengaruh terhadap semangat mempelajari sejarah bangsanya, dan sejarah bangsa-bangsa lain. Dengan semangat belajar sejarah tersebut akan dapat memahami nilai-nilai kebangsaannya yang lebih tinggi atau lebih mendalam. Tingginya pemahaman kebangsaan itu akan dapat menimbulkan sikap cinta bangsa yang lebih tinggi yang dapat mempengaruhi perolehan prestasi belajar sejarah yang lebih tinggi.

Eksistensi lembaga Muhammadiyah di Indonesia, dengan segala cabang kegiatannya termasuk bidang pendidikan menunjukkan suatu usaha mempertahankan dan meningkatkan nilai nasionalisme bangsa Indonesia. Apalagi siswa-siswa SMU, termasuk SMU Muhammadiyah yang merupakan calon ilmuwan, merupakan generasi muda penerus kehidupan bangsa, maka mereka harus melestarikan kehidupan berbangsa dan bernegara. Oleh karena itu, harus ditanamkan nilai-nilai sejarah kebangsaan yang tinggi agar di kemudian hari dapat menjadi warga negara yang berwawasan kebangsaan sehingga dapat menjaga kelangsungan hidup bangsa di masa-masa mendatang. Penanaman nilai kebangsaan atau sikap kebangsaan tersebut dapat melalui pendidikan formal di sekolah dan pendidikan informal dalam keluarga.

Tujuan penelitian ini adalah untuk mengetahui: 1) status sosial ekonomi keluarga terhadap prestasi belajar sejarah; 2) sikap kebangsaan siswa terhadap prestasi belajar sejarah; dan 3) status sosial ekonomi keluarga dan sikap kebangsaan secara bersama-sama terhadap prestasi belajar sejarah. 
Status sosial ekonomi seseorang berkaitan dengan partisipasi seseorang dalam kehidupan bersama sebagai kesatuan hidup bermasyarakat atau kelompok, yang menimbulkan dampak perkembangan dirinya sebagai individu. Sebagaimana pendapat Confusius bahwa kebahagiaan dan kemakmuran akan tetap ada dalam masyarakat jika saja semua orang bertindak 'benar' sebagai anggota keluarga dan menyadari bahwa orang harus mentaati kewajibannya sebagai anggota masyarakat" (William, 2007: 2).

Dalam strata sosial status sosial ada dua istilah yang dijelaskan yaitu perbedaan antara kelas dengan status. Kelas merupakan stratifikasi sosial yang berkenaan dengan hubungan produksi dan penguasaan harta benda, sedangkan status adalah kelompok masyarakat yang merupakan perwujudan stratifikasi sosial, berhubungan dengan prinsip-prinsip yang dianut oleh masyarakat dalam mengonsumsi harta benda sebagaimana dicerminkan oleh gaya hidup secara khusus.

Berdasarkan berbagai pendapat para ahli, penulis menyimpulkan bahwa untuk mencapai kesejahteraan keluarga atau keluarga sejahtera tersebut dengan ukuran terpenuhinya kebutuhan-kebutuhan hidup keluarga pada dasarnya adalah peningkatan pendapatan keluarga. Oleh karena itu, status sosial ekonomi keluarga itu lebih didominasi oleh dimensi pendapatan. Pendapatan keluarga yang tinggi akan menjadi tolok ukur yang sangat penting terhadap tingginya status sosial ekonomi keluarga. Pendapatan keluarga yang tinggi akan menyebabkan terpenuhinya kebutuhankebutuhan keluarga secara luas.

Definisi sikap seperti yang dikemukakan oleh Berkowitz bahwa "sikap adalah suatu bentuk evaluasi atau reaksi perasaan. Sikap seseorang terhadap objek adalah perasaan mendukung atau menolak (favorable) atau perasaan tidak mendukung (unfavorable) objek tersebut" (Azwar, 2009: 4). Menurut formulasi Thurstone "sikap adalah derajat positif atau negatif yang dikaitkan dengan suatu objek psikologis" (Azwar, 2009:5). Menurut Djaali (2008:114) sikap dapat didefinisikan sebagai "kecenderungan untuk bertindak berkenaan dengan objek tertentu". Berdasarkan definisi tersebut dapat ditarik kesimpulan bahwa sikap adalah tindakan seseorang atas dasar perasaan terhadap sesuatu hal. Dalam hal ini bagaimana siswa harus 
bertindak atas perasaannya menghadapi bangsa dan negara setelah memperoleh masukan dari guru tentang sesuatu yang menyejahterakan bangsa dan negara Indonesia, lewat pembelajaran sejarah.

Sikap seseorang dapat terbentuk karena adanya sesuatu yang dapat ia rasakan sebagai seorang diri maupun sebagai kelompok kesatuan hidup. Pembentukan sikap atau attitude itu tidak terjadi dengan sendirinya atau dengan sumbangan, tetapi berlangsung dalam interaksi manusia dan berkenaan dengan objek tertentu. Interaksi sosial di dalam dan di luar kelompok dapat mengubah atau membentuk sikap atau attitude yang baru. Sikap seseorang juga dapat dipengaruhi oleh faktor internal di dalam diri pribadi manusia itu. Dengan kata lain, terbentuknya sikap seseorang disebabkan oleh faktor internal dan faktor eksternal.

Sikap memiliki ciri-ciri tersendiri yang berbeda dengan sifat, motifmotif biogenetis bagi manusia. Adapun ciri-ciri yang dimiliki oleh attitude atau sikap itu secara garis besar sebagai berikut.

(1) Sikap itu dipelajari (learnaility)

(2) Memiliki kestabilan (stability)

(3) Personal - social significance

(4) Berisi dan afeksi

(5) Approach - avoidance directionality (Ahmadi, 2002: 179)

Berdasarkan uraian tersebut, penulis berkesimpulan sebagai berikut.

(1) Sikap dapat dibentuk lewat dipelajari baik yang didukung oleh faktor internal pribadi sendiri, maupun oleh faktor eksternal yang berasal dari kelompok yang dapat berhubungan.

(2) Sikap dapat berubah-ubah atau tidak stabil, tergantung dari suatu keadaan dan objek tertentu.

(3) Sifat sikap lebih spesifik daripada pemilikan pengetahuan, sebab sikap merupakan pengetahuan yang harus disertai dengan tindakan.

(4) Sikap tidak sendiri, akan tetapi selalu memiliki hubungan dengan objek tertentu.

(5) Sikap kebangsaan dapat terbentuk melalui proses pembelajaran dalam mata pelajaran sejarah, sosiologi, antropologi dan sebagainya. 
Kebangsaan atau nasionalisme telah berkembang secara meluas pada abad ke-20 dan menjadi rujukan ideologi dari terbentuknya negara kebangsaan di seluruh dunia. Menurut Worsley (1988), kata nasionalisme itu setidaknya mempunyai tiga arti, yakni 1) persamaan bahasa afiliasi dengan agama tertentu seperti negara Polandia; 2) tujuan untuk mempersatukan negara-negara kecil yang terpecah belah di suatu daerah dengan persamaan bahasa dan tradisi sejarah, seperti di Italia dan Jerman; 3) maksud membebaskan rakyat yang bersangkutan dari pemerintahan asing, seperti Czech, Yunani dan Irlandia.

Rasa nasionalisme itu menimbulkan sikap atau wawasan kebangsaan yang tinggi dan membentuk kepribadian bangsa. Terbentuknya sikap itu dipengaruhi oleh faktor internal yang berasal dari diri pribadi seseorang dan dipengaruhi oleh faktor eksternal yang berasal dari luar diri pribadi seseorang akibat dari hubungan sepihak maupun hubungan timbal balik, maka terbentuknya sikap kebangsaan itu dipengaruhi oleh dua faktor tersebut. Mengingat yang mempengaruhi terbentuknya sikap kebangsaan adalah faktor internal dan faktor eksternal maka terbentuknya sikap kebangsaan bangsa Indonesia pada umumnya dan siswa-siswa SMU Muhammadiyah Kota Surakarta khususnya adalah sebagai berikut.

(1) Faktor internal yaitu unsur dasar berupa perasaan, intelektual yang dimiliki sebagai kebersamaan suatu bangsa yang merasa senasib dan sepenanggungan mencintai bangsa dan negara Indonesia.

(2) Faktor eksternal, yaitu unsur-unsur yang berasal dari luar diri warga negara Indonesia dan siswa-siswa SMU Muhammadiyah Kota Surakarta pada khususnya lewat nasehat, berita dari orang tuanya, membaca majalah, surat kabar, melihat dan mendengarkan radio, televisi, dan sebagainya.

Terbentuknya sikap kebangsaan setiap bangsa di dunia akan dilatarbelakangi oleh faktor eksternal dan internal berbeda-beda. Secara umum bagi bangsa-bangsa daerah koloni atau bekas jajahan itu sikap kebangsaannya terbentuk karena kesamaan bahasa, tradisi, budaya, agama, ras dan karena dibuat sengsara penjajah. 
Prestasi belajar merupakan bagian dari keseluruhan proses belajar dan pembelajaran, sebab prestasi belajar dapat dilihat setelah berakhirnya kontak pembelajaran atau berakhirnya proses belajar. Jika dilihat dari hal tersebut, hasil belajar dapat ditinjau dari sisi siswa dan guru. Dari sisi siswa, hasil belajar merupakan berakhirnya penggal dan puncak proses belajar. Dari sisi guru, tindak mengajar diakhiri dengan proses evaluasi hasil belajar. Oleh karena itu, hasil belajar untuk sebagian adalah berkat tindak guru, suatu pencapaian tujuan pengajaran, dan di pihak lain merupakan peningkatan kemampuan mental siswa. Prestasi belajar merupakan hasil belajar siswa, sebagaimana dikemukakan Hamalik (2007:173) bahwa hasil belajar menunjuk pada prestasi belajar, sedangkan prestasi belajar itu merupakan indikator adanya dan derajat perubahan tingkah laku siswa. Prestasi belajar diperoleh dari adanya kegiatan evaluasi hasil pembelajaran yang memiliki empat sasaran pokok yaitu tujuan pembelajaran, unsur dinamis pembelajaran, pelaksanaan pembelajaran, dan pelaksanaan kurikulum (Hamalik, 2007: 173).

Proses terjadinya prestasi belajar siswa itu karena 1) adanya kontak pembelajaran antara guru dengan siswa; 2) adanya bahan pelajaran yang ditransfer oleh guru dan menarik perhatian siswa; 3) adanya perhatian dan motivasi dari guru maupun siswa; 4) adanya tujuan pembelajaran yang sudah ditetapkan yaitu intelegensia dan estetik; 5) adanya motivasi belajar dan pembelajaran.

Secara umum belajar merupakan perubahan pengetahuan, sikap dan keterampilan hasil dari pengalaman atau latihan. Pengalaman ataupun latihan itu berlangsung dalam proses pembelajaran, sehingga menghasilkan sesuatu dari proses itu yang disebut dengan kinerja belajar atau prestasi belajar.

Prestasi adalah kemampuan nyata yang merupakan hasil interaksi antara berbagai faktor yang mempengaruhi baik dari dalam maupun dari luar individu dalam belajar (Sardiman, 2001:46). Untuk mendapatkan informasi tentang prestasi belajar pada umumnya dan prestasi belajar sejarah, dapat digunakan alat pengukur keberhasilan belajar dalam bentuk tes, baik bentuk ujian tulis "essay" atau bentuk objective test. Dalam menggunakan hasil belajar itu biasanya mencakup aspek kognitif, efektif dan 
psikomotor terutama pada mata pelajaran ilmu-ilmu sosial termasuk sejarah.

Sesuai dengan tujuan pembelajaran yang ingin mengetahui perubahan sikap dan tingkah laku siswa, setelah berlangsungnya proses pembelajaran dalam periode catur wulan dilakukan evaluasi hasil belajar oleh guru. Untuk mengetahui tingkat penguasaan pelajaran oleh siswa, evaluasi tes harus menggunakan sistem penilaian yang sudah distandardisasikan yang disebut sistem penilaian.

Berdasarkan berbagai pendapat, penulis menyimpulkan tentang hakikat prestasi belajar sejarah yakni 1) prestasi belajar sejarah merupakan hasil yang dicapai dari apa yang diusahakan melalui proses belajar sejarah yang dilakukan melalui seperangkat butir soal atau pertanyaan yang dikembangkan untuk mengukur kemampuan yang telah dimiliki siswa sebagai akibat dari proses pembelajaran yang telah diikuti; 2) setiap individu sesuai nalurinya mempunyai keinginan atau kebutuhan untuk berprestasi baik di sekolah maupun di masyarakat, keinginan dan kebutuhan semacam itu dalam rangka meningkatkan harga diri sebagai individu; 3) prestasi belajar siswa diperoleh melalui serangkaian proses penilaian sebagai upaya mengumpulkan informasi untuk mengetahui seberapa jauh pengetahuan dan kemampuan telah dicapai oleh siswa pada akhir pembelajaran menurut standar penilaian yang berlaku.

Kerangka pikir pada penelitian ini dapat diskemakan sebagai berikut:

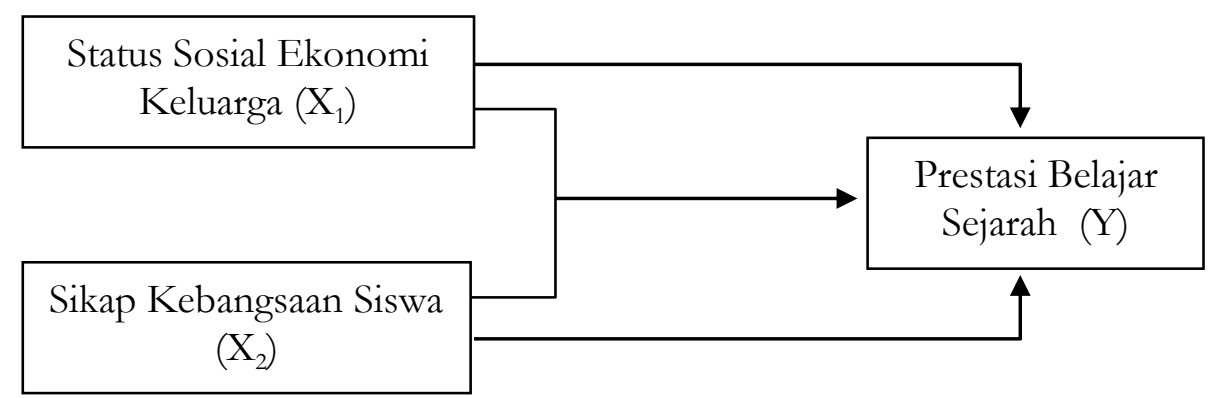

Gambar 1. Kerangka Pikir Penelitian 
Hipotesis penelitian ini yakni 1) status sosial ekonomi keluarga memberikan kontribusi yang positif terhadap prestasi belajar sejarah; 2) sikap kebangsaan memberikan kontribusi yang positif terhadap prestasi belajar sejarah; 3) status sosial ekonomi keluarga dan sikap kebangsaan secara bersama-sama memberikan kontribusi yang positif terhadap prestasi belajar sejarah.

\section{Metode Penelitian}

Penelitian ini dilaksanakan di Sekolah Menengah Umum Muhammadiyah, Wilayah Kantor Pendidikan Nasional Kota Surakarta, Propinsi Jawa Tengah. Penelitian ini dilaksanakan mulai bulan Februari sampai dengan Mei 2010.

Populasi dalam penelitian ini adalah seluruh siswa kelas II (dua) Sekolah Menengah Umum Muhammadiyah kota Surakarta. Jumlahnya sebanyak 980 orang siswa yang berasal dari 24 kelas dalam 10 Sekolah Menengah Umum Muhammadiyah di Surakarta pada tahun 2009/2010.

Sampel dalam penelitian ini adalah sebagian dari populasi, yaitu sebagian dari siswa kelas dua Sekolah Menengah Umum Muhammadiyah Surakarta. Jumlah sampel tersebut sebanyak 245 orang siswa kelas dua SMU Muhammadiyah Surakarta, yang berasal dari 10 kelas siswa kelas dua dalam 24 kelas yang ada.

Definisi operasional dari variabel-variabel tersebut sebagai berikut.

(1) Status sosial ekonomi keluarga adalah tinggi atau rendahnya keadaan keluarga yang disebabkan oleh status sosial dan pendapatan yang dimilikinya.

(2) Sikap kebangsaan adalah pendapat yang dicerminkan pada tingkah laku dan perbedaan seseorang siswa SMU yang menunjukkan rasa memiliki dan ikut bertanggung jawab terhadap kelangsungan hidup bangsa dan negara.

(3) Prestasi belajar sejarah adalah sikap dan pengetahuan yang dimiliki siswa SMU setelah mempelajari sejarah. 
Indikator dari variabel-variabel tersebut.

(1) Indikator Status Sosial ekonomi keluarga meliputi tingkat pendidikan orang tua, tingkat pendapatan/penghasilan keluarga, jumlah keluarga dan tanggungan keluarga, barang-barang yang dimiliki, keadaan rumah, dan mobilitas keluarga atau orang tua.

(2) Indikator Sikap kebangsaan meliputi nilai-nilai persatuan, cinta tanah air, bangsa dan negara, rela berkorban (berbuat untuk kepentingan bangsa dan negara Republik Indonesia).

(3) Indikator Prestasi Belajar Sejarah mencakup hasil belajar yang meliputi aspek kognitif, afektif, dan psikomotor, yang diwujudkan dalam bentuk nilai angka oleh guru sejarah.

Skala pengukuran dari variabel-variabel bebas dan terikat.

1. Status sosial ekonomi keluarga dengan skala sangat kaya, kaya, sedang, miskin (kurang, kurang sekali).

2. Sikap kebangsaan dengan skala sangat setuju, setuju, kurang setuju, sangat kurang setuju.

3. Prestasi belajar sejarah, skalanya adalah dari nilai yang digolongkan sangat baik, baik, sedang, dan kurang.

Teknik pengumpulan data yang digunakan dalam penelitian ini terdiri dari dua macam yaitu angket dan tes. Angket digunakan untuk mengumpulkan data tentang Status Sosial Ekonomi Keluarga dan Sikap Kebangsaan. Tes digunakan untuk memperoleh data tentang prestasi belajar sejarah. Penyusunan angket dan tes dilakukan dengan menyusun kisi-kisi terlebih dahulu. Kisi-kisi disajikan pada Tabel 1 dan Tabel 2.

Agar mendapatkan data yang baik dalam suatu penelitian, data yang diperoleh dari instrumen penelitian atau tes itu harus dibuktikan validitas dan diestimasi reliabilitasnya. Validitas dan reliabilitas ini penting sekali digunakan dalam penelitian sebab berkaitan dengan pengukuran tentang ketepatan dan keajegan alat ukur. Adapun hasil estimasi reliabilitas dalam penelitian ini disajikan pada Tabel 3. 
Tabel 1. Kisi-kisi Instrumen Penelitian Variabel Status Sosial Ekonomi dan Sikap Kebangsaan

\begin{tabular}{|c|c|c|}
\hline Variabel & Indikator & Diskriptor \\
\hline \multirow{10}{*}{$\begin{array}{l}\text { Status } \\
\text { Sosial } \\
\text { Ekonomi }\end{array}$} & \multirow{5}{*}{$\begin{array}{l}\text { Memperankan } \\
\text { diri dalam } \\
\text { kehidupan sosial }\end{array}$} & Jenjang pendidikan orang tua \\
\hline & & Tingkat mobilitas sosial orang tua \\
\hline & & \\
\hline & & $\begin{array}{l}\text { Jumlah anak yang masih hidup dan jumlah } \\
\text { tanggungan dalam keluarga }\end{array}$ \\
\hline & & Pekerjaan dan jenis pekerjaan orang tua \\
\hline & \multirow{5}{*}{$\begin{array}{l}\text { Memperankan } \\
\text { diri dalam } \\
\text { ekonomi } \\
\text { keluarga }\end{array}$} & Besarnya penghasilan orang tua/keluarga \\
\hline & & Besarnya penghasilan anggota keluarga \\
\hline & & Kondisi/kualitas rumah \\
\hline & & Pemilikan barang-barang rumah tangga \\
\hline & & Alat transportasi keluarga \\
\hline \multirow[t]{8}{*}{$\begin{array}{l}\text { Sikap } \\
\text { Kebangsaan }\end{array}$} & \multirow{3}{*}{$\begin{array}{l}\text { Semangat } \\
\text { persatuan dan } \\
\text { kesatuan }\end{array}$} & $\begin{array}{l}\text { Membina kerukunan dan kesatuan kelompok } \\
\text { masyarakat }\end{array}$ \\
\hline & & $\begin{array}{l}\text { Menempatkan kepentingan bangsa di atas } \\
\text { kepentingan pribadi/golongan }\end{array}$ \\
\hline & & Cinta tanah air Indonesia \\
\hline & \multirow{2}{*}{$\begin{array}{l}\text { Memiliki } \\
\text { kesadaran } \\
\text { nasional }\end{array}$} & $\begin{array}{l}\text { Tekad kuat untuk membangun masa depan } \\
\text { bersama. }\end{array}$ \\
\hline & & Pandangan hidup bangsa \\
\hline & \multirow{3}{*}{$\begin{array}{l}\text { Memiliki jati diri } \\
\text { bangsa }\end{array}$} & Memilih dan mengolah unsur-unsur budaya asing \\
\hline & & Menumbuhkan dan melestarikan budaya daerah \\
\hline & & $\begin{array}{l}\text { Kesadaran akan kedudukan persamaan derajat } \\
\text { yang sama dengan bangsa lain. }\end{array}$ \\
\hline
\end{tabular}


Tabel 2. Kisi-kisi Instrumen Penelitian Variabel Prestasi Belajar Sejarah

\begin{tabular}{|c|c|c|c|}
\hline Prestasi & \multicolumn{3}{|c|}{ Latar belakang lahirnya pergerakan nasional } \\
\hline $\begin{array}{l}\text { Belajar } \\
\text { Sejarh }\end{array}$ & \multicolumn{3}{|c|}{ Bentuk dan strategi organisasi pergerakan nasional Indo } \\
\hline & \multicolumn{3}{|c|}{$\begin{array}{l}\text { Azas perhimpunan Indonesia sebagai manifesto politik } \\
\text { pergerakan nasional }\end{array}$} \\
\hline & \multicolumn{3}{|c|}{ Ide persatuan dan kesatuan } \\
\hline & \multicolumn{3}{|c|}{$\begin{array}{l}\text { Pergerakan nasional pada masa pendudukan Jepang di } \\
\text { Indonesia }\end{array}$} \\
\hline & \multicolumn{3}{|c|}{ Akibat penjajahan Jepang } \\
\hline & \multicolumn{3}{|c|}{ Persiapan kemerdekaan Indonesia } \\
\hline & \multicolumn{3}{|c|}{ Tabel 3. Hasil Estimasi Reliabilitas } \\
\hline & Variabel & $\begin{array}{l}\text { Jumlah } \\
\text { soal/pertanyaan }\end{array}$ & Reliabilitas \\
\hline & kap Kebangsaan & 40 & 0,921 \\
\hline & restasi Belajar Sejarah & 50 & 0,747 \\
\hline
\end{tabular}

Ada dua langkah pokok dalam analisis data yaitu 1) uji persyaratan analisis dan 2) analisis data untuk pengujian hipotesis yang diajukan. Persyaratan-persyaratan yang harus dipenuhi adalah sebagai berikut 1) sampel yang diambil secara acak; 2) bentuk distribusi variabel bebas dan terikat dalam populasi haruslah normal atau mendekati normal dan independen; 3) hubungan antara variabel bebas dengan variabel terikat merupakan hubungan linear. Syarat pertama telah terpenuhi pada teknik penentuan sampel.

Teknik analisis data yang dipergunakan pada penelitian ini adalah analisis regresi sederhana dan regresi ganda. Analisis regresi sederhana dipergunakan untuk menguji hipotesis pertama dan kedua, sedangkan analisis regresi ganda dipergunakan untuk menguji hipotesis ketiga. 


\section{Hasil Penelitian dan Pembahasan}

Hasil analisis statistik deskriptif disajikan pada Tabel 4.

Tabel 4. Deskripsi Data Penelitian

\begin{tabular}{llcccc}
\hline No & \multicolumn{1}{c}{ Nilai Data } & Rerata & Median & Modus & $\begin{array}{c}\text { Simpangan } \\
\text { Baku }\end{array}$ \\
\hline 1 & X $_{1}$ (status sosial ekonomi) & 146,88 & 146,405 & 145,30 & 8,399 \\
2 & X $_{2}$ (sikap kebangsaan) & 184,39 & 184,245 & 184,11 & 8,233 \\
3 & Y (prestasi belajar sejarah) & 29,12 & 28,91 & 27,19 & 4,648 \\
\hline
\end{tabular}

Sebelum dilakukan analisis data untuk pengujian hipotesis, terlebih dahulu dilakukan uji prasyarat analisis. Adapun hasil uji prasyarat analisis tersebut adalah sebagai berikut.

1. Hasil Uji Normalitas

Tabel 5. Hasil Uji Normalitas Data

\begin{tabular}{lccc}
\hline \multicolumn{1}{c}{ Variabel } & $\chi^{2}$ hitung & $\chi^{2}$ tabel 0,05 & Kesimpulan \\
\hline $\mathrm{X}_{1}$ (status sosial ekonomi) & 3,987 & 9,49 & Normal \\
$\mathrm{X}_{2}$ (sikap kebangsaan) & 1,182 & 9,49 & Normal \\
$\mathrm{Y}$ (prestasi belajar sejarah) & 4,379 & 9,49 & Normal \\
\hline
\end{tabular}

2. Hasil Uji Linearitas

Hasil uji linieritas $\mathrm{X}_{1}$ terhadap $\mathrm{Y}$ diperoleh harga $\mathrm{F}$ hitung $=1,41$ lebih kecil dari $F$ tabel 1,45 dengan $\alpha=0,05$, dengan kesimpulan bahwa hubungan $\mathrm{X}_{1}$ (status sosial ekonomi)dengan $\mathrm{Y}$ (prestasi belajar sejarah)linear. Persamaan regresi $\mathrm{Y}$ atas $\mathrm{X}_{1}$ diperoleh $\hat{Y}=1,3899+0,1889 X_{1}$. Harga $\mathrm{F}$ hitung sebesar 30,45 lebih besar dari F tabel dengan $\alpha=0,05$ sebesar 3,89 hal ini berarti bahwa koefisien arah regresi Status Sosial Ekonomi Keluarga Siswa Kelas dua Sekolah Menengah Umum Muhammadiyah kota Surakarta dengan Prestasi Belajar Sejarah Nasional Indonesia adalah berarti. 
Hasil uji linieritas $\mathrm{X}_{2}$ (sikap kebangsaan) terhadap $\mathrm{Y}$ (prestasi belajar sejarah) diperoleh harga $\mathrm{F}$ hitung sebesar 1,06 lebih kecil dari $\mathrm{F}$ tabel 1,45 dengan $\alpha=0,05$, dengan kesimpulan bahwa hubungan $\mathrm{X}_{2}$ dengan $\mathrm{Y}$ adalah linear. Persamaan regresi $\mathrm{Y}$ atas $\mathrm{X}_{2}$ diperoleh $\hat{Y}=0,6235+0,1545 X_{2}$. Harga $F$ hitung sebesar 20,35 lebih besar dari $F$ tabel dengan $\alpha=0,05$ sebesar 3,89. Hal ini menunjukkan bahwa koefisien arah regresi bersifat nyata, sehingga regresi Sikap Kebangsaan dengan Prestasi belajar Sejarah adalah berarti.

\section{Hasil Uji Independensi}

Hasil uji independensi antara variabel Status Sosial Ekonomi Keluarga $\left(\mathrm{X}_{1}\right)$ dengan Sikap Kebangsaan $\left(\mathrm{X}_{2}\right)$ menunjukkan bahwa kedua variabel tersebut tidak ada hubungan (independensi/saling bebas) sebab harga $t_{\text {hitung }} 1,3$ lebih kecil dari $t_{\text {tabel }} 1,96$.

Hasil Analisis Data

a. Kontribusi Status Sosial Ekonomi Keluarga terhadap Prestasi Belajar Sejarah Nasional Indonesia

Persamaan regresi $\mathrm{Y}$ atas $\mathrm{X}_{1}$ diperoleh $\hat{Y}=1,3899+0,1889 X_{1}$. Hal ini berarti bahwa setiap ada perubahan $\mathrm{X}_{1}$ sebesar 1 satuan, maka akan terjadi perubahan positif pada Y sebesar 1,3899 satuan.

Harga $\mathrm{F}$ hitung sebesar 30,45 lebih besar dari $\mathrm{F}$ tabel dengan $\alpha=$ 0,05 sebesar 3,89 hal ini berarti bahwa koefisien arah regresi Status Sosial Ekonomi Keluarga Siswa Kelas dua Sekolah Menengah Umum Muhammadiyah kota Surakarta dengan Prestasi Belajar Sejarah Nasional Indonesia adalah berarti.

b. Kontribusi Sikap Kebangsaan terhadap Prestasi Belajar Sejarah

Persamaan regresi $\mathrm{Y}$ (prestasi belajar sejarah) atas $\mathrm{X}_{2}$ (sikap kebangsaan) diperoleh $\hat{Y}=0,6235+0,1545 X_{2}$. Hal ini berarti bahwa setiap ada perubahan $\mathrm{X}_{2}$ sebesar 1 satuan, maka akan terjadi perubahan positif pada $\mathrm{Y}$ sebesar 0,6235 satuan.

122 - Jurnal Penelitian dan Evaluasi Pendidikan Tahun 17, Nomor 1, 2013 
Harga $\mathrm{F}$ hitung $=20,35$ lebih besar dari $\mathrm{F}$ tabel dengan $\alpha=0,05$ sebesar 3,89. Hal ini menunjukkan bahwa koefisien arah regresi bersifat nyata, sehingga regresi Sikap Kebangsaan dengan Prestasi belajar Sejarah adalah berarti.

c. Kontribusi Sikap Sosial Ekonomi Keluarga dan Sikap Kebangsaan terhadap Prestasi Belajar Sejarah.

Hasil analisis korelasi ganda diperoleh nilai $\mathrm{R}_{\mathrm{y}(1.2)}=0,409>\mathrm{R}_{\mathrm{t}}=$ 0,138 , untuk $\mathrm{n}=245$ pada $\alpha=0,05$. Hal ini menunjukkan bahwa $\mathrm{R}$ terbesar 0,409 adalah signifikan, sebab $\mathrm{R}_{\mathrm{y}(1.2)}$ lebih besar dari $\mathrm{R}_{\mathrm{t}}$ yang hanya sebesar 0,138. Oleh karena itu ada kontribusi yang positif dan meyakinkan antara status sosial ekonomi keluarga dan sikap kebangsaan terhadap prestasi belajar sejarah. Hasil F hitung 24,33 > F tabel 3,04. Hal ini bahwa terdapat hubungan yang berarti antara $\mathrm{X}_{1}$ dan $\mathrm{X}_{2}$ dengan $\mathrm{Y}$. Persamaan garis regresi ganda $\hat{\mathrm{Y}}=20,502+0,1714 \mathrm{X}_{1}+0,1327 \mathrm{X}_{2}$. Uji keberartian persamaan garis regresi ganda diperoleh $\mathrm{F}$ hitung sebesar 24,33 dan $\mathrm{F}$ tabel sebesar 3,04, sehingga menunjukkan bahwa garis regresi berarti atau nyata.

Berdasarkan hasil perhitungan dari skor rata-rata data tentang Status Sosial Ekonomi Keluarga siswa kelas dua SMU Muhammadiyah sekota Surakarta sebesar 146,878. Hasil perhitungan tersebut dapat diklasifikasikan baik sebab dari 245 subyek penelitian terdapat 124 diantaranya memperoleh nilai di atas rata-rata ini berarti bahwa sebagian besar siswa Sekolah Menengah Umum Muhammadiyah sekota Surakarta memiliki keluarga yang berstatus ekonomi baik atau di atas rata-rata pendapatan.

Deskripsi data Sikap Kebangsaan menunjukkan skor rata-rata sebesar 184,388, ini berarti dapat diklasifikasikan cukup, sebab dari 245 subjek penelitian terdapat hampir 50\% di antaranya yang memperoleh nilai di atas rata-rata $(48,16 \%)$. Oleh karena itu, dapat diartikan bahwa sebagian besar siswa Sekolah Menengah Umum Muhammadiyah sekota Surakarta cukup memiliki pemahaman tentang nilai-nilai kebangsaan, dengan demikian dapat meningkatkan prestasi belajarnya. Hal ini sangat penting agar para siswa dapat mempelajari berbagai makna dari peristiwa-peristiwa sejarah di masa lampau yang mengandung nilai kebangsaan atau nilai dan sikap 
nasionalisme sebagai bangsa yang merdeka untuk menghadapi berbagai tantangan nilai-nilai kebangsaan di masa-masa mendatang.

Perhitungan skor rata-rata data prestasi belajar sejarah sebesar 29,12, ini dapat diklasifikasikan cukup/kurang karena dari 245 subjek penelitian terdapat $43,26 \%$ di antaranya memperoleh nilai di bawah rata-rata, ini berarti bahwa sebagian besar siswa kelas dua Sekolah Menengah Umum Muhammadiyah kota Surakarta memiliki prestasi belajar sejarah kurang baik. Sungguhpun demikian, perlu ditingkatkan dalam membina mental psikologis siswa sebagai generasi penerus bangsa dalam menghadapi berbagai tantangan yang mungkin terjadi.

Hasil perhitungan memberikan kejelasan bahwa status sosial ekonomi keluarga dapat memberikan kontribusi terhadap prestasi belajar sejarah siswa kelas dua SMU Muhammadiyah sekota Surakarta. Hal ini dapat terlihat pada hasil perhitungan yang besarnya kontribusi status sosial ekonomi keluarga terhadap prestasi belajar sejarah yakni 9,02\%. Persentase ini cukup meyakinkan sungguhpun dalam pencapaian prestasi belajar sejarah siswa banyak faktor yang juga dapat memberikan pengaruh kontribusi yang tak diteliti dalam penelitian ini.

Tentu saja berbagai faktor yang turut menentukan tinggi atau rendahnya prestasi belajar siswa itu seperti motivasi, sikap, tingkat kecerdasan, kesehatan fisik, lingkungan sosial, lingkungan sekolah, peranan guru, dan sebagainya. Guru dapat dikatakan sebagai pemeran utama dalam pencapaian hasil belajar jika guru dapat mengembangkan kompetensinya, sehingga diharapkan dapat meningkatkan kualitas mengajarnya, mampu membentuk sikap positif siswa terhadap nilai-nilai luhur perjuangan bangsa di samping hasil yang dicapainya. Demikian pula orang tua yang mampu ekonominya dan berstatus sosial yang tinggi akan dapat diharapkan ikut membentuk sikap anak-anak untuk maju belajar menghadapi tantangan yang semakin berat dimasa-masa mendatang. Tantangan itu di antaranya dapat diatasi dengan pemilikan ilmu pengetahuan dan teknologi yang tinggi dan banyak, yang digambarkan pada pencapaian prestasi belajar.

Hasil perhitungan memberikan kejelasan bahwa sikap kebangsaan dapat memberikan kontribusi terhadap prestasi belajar sejarah bagi siswa kelas dua SMU Muhammadiyah sekota Surakarta.Kontribusi itu akan 
terlihat pada hasil perhitungan besarnya kontribusi sikap kebangsaan terhadap prestasi belajar sejarah yakni sebesar 5,59\%. Persentase ini cukup berarti sebab dalam pencapaian hasil belajar pada umumnya dan hasil belajar sejarah pada khususnya banyak faktor pula yang dapat ikut memberikan pengaruh kontribusi yang tidak termasuk diteliti dalam penelitian ini.

Selain faktor sikap kebangsaan tentunya ada banyak pula faktor yang ikut mempengaruhi terhadap pencapaian prestasi belajar siswa. Faktorfaktor itu diantaranya adalah peranan guru dalam membelajarkan sejarah, lingkungan sosial, lingkungan sekolah dan lingkungan keluarga serta kestabilan kesehatan fisik dan mental siswa. Sikap kebangsaan perlu sekali dikembangkan lewat proses pendidikan di sekolah sebab sekolah sebagai lembaga pencetak kader-kader bangsa yang demokratis, cakap, cinta bangsa dan tanah air serta bertanggung jawab terhadap kelangsungan hidup bangsa dimasa-masa mendatang.

Dari analisis statistik korelasi ganda diperoleh hasil bahwa nilai $\mathrm{R}_{\mathrm{y} .1 .2}$ sebesar 0,4092 dengan uji keberartian yang menggunakan uji $\mathrm{F}$ dengan diperoleh nilai $F$ sebesar 24,33. Harga nilai $F$ ini lebih besar dari $F$ pada tabel distribusi $\mathrm{F}$ sebesar 3,04 dari hasil analisis ini menunjukkan bahwa ada hubungan antara status sosial ekonomi keluarga siswa kelas dua SMU Muhammadiyah sekota Surakarta dan sikap kebangsaan secara bersamasama, terhadap prestasi belajar sejarah sebesar 2,13\%.

Kenyataan itu menunjukkan bahwa sikap kebangsaan lebih memberikan kontribusi terhadap prestasi belajar sejarah selain status sosial ekonomi keluarga. Hal ini dapat dilihat dari kontribusi sikap kebangsaan terhadap prestasi belajar sejarah sebesar 9,02\%, dan kontribusi status sosial ekonomi sosial keluarga terhadap prestasi belajar sejarah sebesar 5,59 \%.

\section{Simpulan}

Berdasarkan hasil penelitian dan pembahasan, dapat disimpulkan sebagai berikut 1) terdapat kontribusi atau sumbangan yang positif dan signifikan antara status sosial ekonomi keluarga terhadap prestasi belajar sejarah, dengan sumbangan relatif (SR) sebesar 60,36\% dan sumbangan efektif (SE) 
sebesar $9,02 \%$; 2) terdapat kontribusi atau sumbangan yang positif dan signifikan antara sikap kebangsaan terhadap prestasi belajar sejarah, dengan sumbangan relatif (SR) nya sebesar 39,64\% dan sumbangan efektif (SE) nya sebesar 5,59\%; 3) erdapat kontribusi atau sumbangan positif dan signifikan status sosial ekonomi keluarga dan sikap kebangsaan secara bersama-sama terhadap prestasi belajar sejarah, dengan sumbangan relatif (SR) nya sebesar 100\% dan sumbangan efektif (SE) nya sebesar 2,13\%.

\section{Daftar Pustaka}

Ahmadi, Abu. (2002). Psikologi sosial. Jakarta: Rineka Cipta.

Djaali. (2008). Psikologi pendidikan. Jakarta: Bumi Aksara.

Hamalik, Oemar. (2007). Kurikulum dan pembelajaran. Jakarta: Bumi Aksara.

Azwar, Saifuddin. (2009). Sikap manusia, teori dan pengukurannya. Yogyakarta: Pustaka Pelajar

Sardiman AM. (2001). Interaksi dan motivasi belajar mengajar. Jakarta: PT Raja Grafindo Persada.

Malian, Sobirin \& Marzuki, Suparman. (2003). Pendidikan kewarganegaraan dan hak asasi manusia. Yogyakarta: UII Press.

William J. Goode,. (2007). Sosiologi keluarga. Terjemahan Laila hanoum Hasyim. Jakarta: Bumi Aksara.

Worsley, Peter, (1988). The new introducing of socilogy. edited by: peter worsley, London: Penguin Books Ltd. 